\title{
Corporate Boards: Control through Representation and Accounting Standards in Small and Medium Enterprises (SME).
}

\author{
Ph.D.Rezart DIBRA \\ College University of Business Tirana Albania,Vangjel Noti,Tirane \\ Assoc Prof. Ylber BEZO \\ College University of Business Tirana Albania,Vangjel Noti,Tirane
}

\begin{abstract}
Today the company has adopt the accounting standards and corporate governance (CG) standards.CG is at the topic of all the lesson of management. The corporate governance and management has important role in every company, but the role of implementing standards of accounting is most important. Effective corporate governance requires a clear understanding of the respective roles of the board, management and shareholders; their relationships with each other; and their relationships with other corporate stakeholders.

This paper is a theoretical study about the corporate governance and the role of company in corporate governance and the role of accounting standards in SME.
\end{abstract}

Keywords: corporate governance, accounting standards, board of directors etc.

DOI: $10.7176 /$ RJFA/11-17-07

Publication date:October $31^{\text {st }} 2020$

\section{Introduction}

At the heart of every governance system is a board ( or boards) of corporate directors, charged with directing and overseeing corporate affairs. If one views the board as an institution of control through representation, one must recognize a multitude of its possible organizational arrangements. Just as a variety of mechanisms of political representation-from different structures of parliamentary bodies through different requirements for political representation-from different structures of parliamentary bodies through different requirements for political representation to different election procedures- is compatible with a genuine political governance, so is a variety of different arrangements of corporate boards compatible with a genuine business governance. A particular arrangement tends to reflect historical, socioeconomic, political, and cultural factors unique to a particular country much the same way its political governance system does.

This is not to say that the way control through representation is organized is irrelevant. However, the real impact of corporate boards-the scope and efficacy of their command- depends not so much on how the representation is arranged but on who the owners are, what benefits they derive from their ownership, and what alternatives to control through board representation they have. These factors underlay the expectations which corporate constituencies place with corporate boards, and effectively determine the power these board have.

The identity of corporate owners matters with matters with respect to at least two characteristics: the size of their holdings, and the nature of benefits these holding entail. Ownership scattered among a large number of small shareholder creates different control problems than ownership concentrated in a few hands, either directly or institutionally. In the former case, the central problem is that of insufficient control stemming from the lack of commitment of individual owners : effective control requires a collective action but each owner has an incentive to free ride on the commitment of others. In the latter case, large owners have both the incentive and the leverage to enforce their will with relative ease. The power to compel, however, creates a problem of its own, that of impervious control stemming from possible entrenchment of the dominant owners.

\section{The role of board of director in management operational}

The board of directors has the vital role of overseeing the company's management and business strategies to achieve long-term value creation. Selecting a well-qualified chief executive officer (CEO) to lead the company, monitoring and evaluating the CEO's performance, and overseeing the CEO succession planning process are some of the most important functions of the board. The board delegates to the CEO - and through the CEO to other senior management - the authority and responsibility for operating the company's business. Effective directors are diligent monitors, but not managers, of business operations. They exercise vigorous and diligent oversight of a company's affairs, including key areas such as strategy and risk, but they do not manage - or micromanage - the company's business by performing or duplicating the tasks of the CEO and senior management team. The distinction between oversight and management is not always precise, and some situations (such as a crisis) may require greater board involvement in operational matters. In addition, in some areas (such as the relationship with the outside auditor and executive compensation), the board has a direct role instead of an oversight role.

- Management, led by the CEO, is responsible for setting, managing and executing the strategies of the 
company, including but not limited to running the operations of the company under the oversight of the board and keeping the board informed of the status of the company's operations. Management's responsibilities include strategic planning, risk management and financial reporting. An effective management team runs the company with a focus on executing the company's strategy over a meaningful time horizon and avoids an undue emphasis on short-term metrics.

- Shareholders invest in a corporation by buying its stock and receive economic benefits in return. Shareholders are not involved in the day-to-day management of business operations, but they have the right to elect representatives (directors) and to receive information material to investment and voting decisions. Shareholders should expect corporate boards and managers to act as long-term stewards of their investment in the corporation. They also should expect that the board and management will be responsive to issues and concerns that are of widespread interest to long-term shareholders and affect the company's long-term value. Corporations are for-profit enterprises that are designed to provide sustainable long-term value to all shareholders. Accordingly, shareholders should not expect to use the public companies in which they invest as platforms for the advancement of their personal agendas or for the promotion of general political or social causes.

- Some shareholders may seek a voice in the company's strategic direction and decisionmaking-areas that traditionally were squarely within the realm of the board and management. Shareholders who seek this influence should recognize that this type of empowerment necessarily involves the assumption of a degree of responsibility for the goal of long-term value creation for the company and all of its shareholders.

A corporation's business is managed under the board's oversight. The board also has direct responsibility for certain key matters, including the relationship with the outside auditor and executive compensation. The board's oversight function encompasses a number of responsibilities, including:

- Selecting the CEO. The board selects and oversees the performance of the company's CEO and oversees the CEO succession planning process.

- Setting the "tone at the top." The board should set a "tone at the top" that demonstrates the company's commitment to integrity and legal compliance. This tone lays the groundwork for a corporate culture that is communicated to personnel at all levels of the organization.

- Approving corporate strategy and monitoring the implementation of strategic plans. The board should have meaningful input into the company's long-term strategy from development through execution, should approve the company's strategic plans and should regularly evaluate implementation of the plans that are designed to create long-term value. The board should understand the risks inherent in the company's strategic plans and how those risks are being managed.

\section{Corporate board}

Under American law, the business of the corporation is to be managed under the direction of a single board of directors. The law does not separate executive and non-exceptive functions among corporate directors: it charges the board as a whole to direct the corporation. The German board system consists of two bodies : a supervisory board, which is composed entirely of non-executive directors, and a managing board, which is composed entirely of non-executive directors, and a managing board, which is composed exclusively of executive directors.

\section{Agency theory.}

Agency theory and transaction cost theory are most important theory in corporate governance. Agency theory defines the relationship between the principals (such as shareholders of company) and agents (such as directors of company). According to this theory, the principals of the company hire the agents to perform work. The principals delegate the work of running the business to the directors or managers, who are agents of shareholders. The shareholders expect the agents to act and make decisions in the best interest of principal. On the contrary, it is not necessary that agent make decisions in the best interests of the principals. The agent may be succumbed to selfinterest, opportunistic behavior and fall short of expectations of the principal. The key feature of agency theory is separation of ownership and control. The theory prescribes that people or employees are held accountable in their tasks and responsibilities. Rewards and Punishments can be used to correct the priorities of agents.

\section{Market for Corporate Control}

Proponents of agency theory define the market for corporate control as an important path in disciplining agents (managers) and fostering their motivation to act in the best interest of the principal (investor). The mechanism to achieve this is the desire of managers to avoid hostile acquisitions of their companies (as there is a high probability that they will lose their job). In conclusion, managers try to maintain a "high" rating for shares. High stock valuation has a number of advantages for managers. For one reason, a high stock value means it is less expensive to get extra finance from the stock market. But the main benefit for managers, in terms of job security, is that a high stock rating makes it more costly for "predators" (large corporations that buy smaller ones) to take control of 
the situation. According to the rules of the agency, managers feel responsible for meeting the requirements of investors, so high stock valuation is attractive to primaries as well.

Some argue that the agent-primary model focuses exclusively on the interests of investors. But it can happen that managers are more concerned with shareholders who are only interested in short-term benefits and consequently neglect long-term benefits. Blai (1995) refers to situations as "market myopia". Short-term gains are created by long-term performance sacrifices. One possible solution to this problem is by encouraging long-term investors. But the main concern is that "what is optimal for investors is usually not optimal for the rest of society. This means that corporate policies that generate the greatest benefits for investors may not be policies that generate social benefit. (Blair, 1995: 13).

According to agency theory, the firm's main goal is to maximize investor profitability. Proponents of the claimant theory argue that these narrow objectives do not go hand in hand with the responsibilities of modern corporations which have a particular consideration for customer relations, suppliers, and the environment.

Proponents of agency theory, however, argue that any corporate governance reform should be driven by a common interest between managers and investors, for example by rewarding directors with annual bonuses according to the company's profit margins. The overall bonus that is enjoyed by directors tends to reinvest in the company and helps it create the financial resources to spend more on research and development projects which are vital to long-term objectives. As a result of this action will be other actors who will benefit from this situation. For example, employees will benefit from increased occupational safety and the environment will benefit from investments to improve efficiency and protect the environment.

In other words, looking at it from the perspective of agency theory, profit maximization can be matched to the improvement of all actors and investors. In this context, an important element is the independence of the board of directors which helps to coordinate the interests of the primary and the agent by allowing the primary to better monitor the actions of the agents and thus helps to resolve the problems between the primary and the agent. it (Hermalin and Weisbach, 2003).

\section{Transaction Cost Theory}

Transaction cost theory states that a company has number of contracts within the company itself or with market through which it creates value for the company. There is cost associated with each contract with external party; such cost is called transaction cost. If transaction cost of using the market is higher, the company would undertake that transaction itself.

All companies, regardless of legal form, are required to prepare annual financial statements in accordance with the Law on Accounting and Financial Reporting.

The statutory audit is required to audit and report on compliance of annual financial statements as defined based on the Accounting Law.

As all the companies and SME has their financial statements. The statements are important to do with all the requirements of law.The types and needs of users of SME financial statements are often different from the types and needs of users of public company financial statements and other entities that would likely use full IFRS. Full IFRS were designed to meet the needs of equity investors in companies in public capital markets. Users of the financial statements of SMEs (or private companies in the U.S.) don't generally have those same needs. Rather, users of the financial statements of SMEs are more focused on shorter-term cash flows, liquidity, balance sheet strength, interest coverage and solvency issues. Also, full IFRS impose a burden on SME preparers in that full IFRS contains topics and detailed implementation guidance that generally are not relevant to SMEs. This burden has been growing as IFRS have become more detailed. As such, a significant need existed for an accounting and financial reporting standard for SMEs that would meet the needs of their financial statement users while balancing the costs and benefits from a preparer perspective. IFRS for SMEs was designed to meet that need. With the issuance of IFRS for SMEs, many SMEs around the world, including private companies in the United States, will have the option of using a much simplified, IFRS-based accounting framework to prepare their financial statements.

\section{Conclusion}

In conclusion the corporate governance and all the theory of governance are most important but the company will adopt and standard of accounting. Both standard of accounting and corporate governance are most important.

All the company has their interest in implementing the standards because the management has the interest to gain the profit. The profit in market economy is very important and without corporate governance and standards of accounting it is impossible to make the profit. All the company in the same time but SME are required to fulfill all the requiremts of accounting standards.

\section{References}

Aghion P and Bolton P (1992), “An incomplete contracts approach to financial contracting”, Review of Economic 
Studies, Vol.59: 473-94

Berle A and Means G (1932), “ The Modern Corporation and Private Property, New York: Macmillan

Blair, M (1995), "Ownership and control: Rethinking Corporate Governance for the Twenty-First Century, Washington DC, The Brookings Institution

Donaldson T and Preston L (1995), "The stakeholder theory of the corporation: concepts, evidence and implications", Academy of Management Review, Vol.20, Nr 1, 65-91

Gamble A and Kelly G (2001), "Shareholder value and the stakeholder debate in the UK", Corporate Governance: An International Review, Vol.9 Nr.2, 110-17

Graham P (1994), "The registrar in the John Lew is partership plc" in G. Vinten, Whisteblowing: Subversion or corporate citizenship? London: Paul Chapman

Hart O (1995), "Firms, Contracts and Financial Structure", Oxford: Claredon Press

Hermalin B and Weisbach M (2003), "Boards of Directors as an endogenously determined institution: a survey of the economic literature", FRBNY Economic policy review, April 7-26

Hill C and jones T (1992), "Stakeholder agency theory", Journal of Management Studies, Vol.29, Nr.2 131-54

Jensen M (2001), "Value maximization, stakeholder theory and the corporate objective function", European Financial Management, Vol.7, Nr 3, 297-317.

Https://corpgov.law.harvard.edu/2016/09/08/principles-of-corporate-governance

Https://www.papertyari.com/general-awareness/management/theories-corporate-governance-agencystewardship-etc.

Https://www.ifrs.com/overview/IFRS_SMES/IFRS_SMES_FAQ.html

In search of good directors. A project of The central European University Foundation and The Center for International Private Enterprise,1998.CIPE. 